\title{
Economic Power Comparison between United States and China in the Context of Covid-19 Pandemic: Based on Statistical Methods
}

\author{
Yutong Yang ${ }^{1}$ \\ ${ }^{1}$ Beijing No.4 High School International Campus Beijing, China
}

\begin{abstract}
Generally speaking, economic crises are caused by insufficient demand, while the economic crisis that may be caused by the Covid-19 epidemic started with insufficient supply. In the case of insufficient demand, countries often use a series of monetary policies to release liquidity, such as interest rate cuts, RRR cuts. However, the interest rate cut this time may not work well. This is because the interest rate cut can increase the liquidity of the market.

While controlling the epidemic, we should promptly resume work and production, and produce a variety of commodities that meet consumer demand. During this period of time, the main strategy is not monetary policy. Instead, appropriate fiscal policies should be used to reduce the burden on enterprises so that they can survive this difficult time without dying before they start their careers. Only companies that can survive the epidemic are good companies that have combat effectiveness and can continue to conquer the market after the epidemic is over.

Therefore, in the face of the Covid-19 epidemic, the competition between China and the United States should not be a zero-sum game because the United States is the final consumer of a large number of products produced by China, and the United States is still the world's leader. If the US economy declines, it will definitely affect global economic development. When necessary, we also need to support the production of high-end consumer products in the United States and allocate a portion of the production capacity for them. Only when the two sides have healthy competition can the industrial chain of both sides be upgraded together.
\end{abstract}

\section{Introduction}

As the number of Covid-19 infections and deaths increased, major global stock markets collapsed, and the FTSE, Dow Jones Industrial Average (DJIA) and Nikkei all fell sharply. The DJIA and FTSE indexes experienced their biggest quarterly declines since 1987 in the first three months of this year[1]. Central banks in many countries, including the United Kingdom, have lowest interest rates. Theoretically, that should make borrowing cheaper and encourage spending to stimulate the economy. Since then, with government intervention, the global market began to recover. However, unless people's concerns about the second round of the pandemic are eased, the stock market will experience severe volatility.

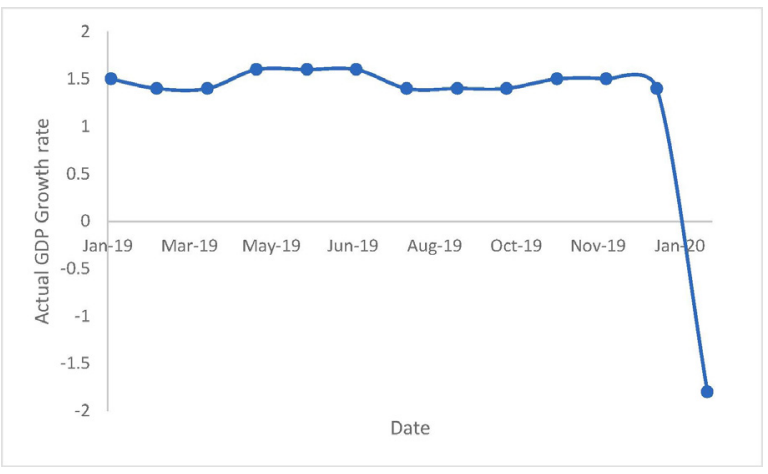

Figure 1 Mean monthly GPD growth rate in China

If the economy keeps growing, that usually means more wealth and more new jobs. Economic growth is measured by the percentage change in gross domestic product (GDP) or the value of goods and services produced (usually more than three months or a year). However, the International Monetary Fund (IMF) said the global economy will shrink by $3 \%$ this year[2]. This recession is the worst since the Great Depression of the 1930s. However, the IMF claims that the coronavirus has plunged the world into an unparalleled crisis if the 
epidemic subsides in the second half of 2020, the global economy is expected to grow by $5.8 \%$ next year[3]. This will be mainly driven by growth in countries such as China and India. It is expected that the recovery of service-dependent developed economies such as the United Kingdom that have been severely affected by the epidemic will be a slow process.

According to the data from the International Monetary Fund (IMF), the proportion of the unemployed in the United States has reached $10.4 \%$, which marks the end of the ten-year expansion of one of the world's largest economies. Some industries (such as the tourism industry or the hotel industry) have been hit by quarantine and epidemic prevention measures[4]. Millions of industry operators have joined the government-supported job retention program, that is, suspension of pay and lay-off waiting for work. The epidemic has the greatest impact on travel and related industries. Customs, lockdown, and quarantine measures have caused airlines to suspend or cut flights, and customers cancel business trips and holidays. Many countries impose travel restrictions to try to control virus import.

In the first two quarters, China's economic growth faced tremendous pressure. China's production, retail consumption and tourist numbers dropped significantly, and regional trade, transportation and tourism worldwide dropped significantly. It is worth noting that many major factors at the time of prior epidemic events are different from Covid-19, so reference significance is limited[5]. Firstly, the current quarantine of the new Covid-19 is larger and broader. The economic impact of the current epidemic is not just the impact of its severity. This reaction and response may have a greater economic impact than prior economic situation affected by global and regional epidemic spread like SARS and Ebola[6]. Secondly, the most affected industries are consumption and services, which currently account for a much larger share of the Chinese economy. China rebalanced its dependence on exports and investment, China has become more susceptible to slowing domestic demand, and the decline in domestic consumption of goods and services will have a greater impact on the overall economy[7]. Now China is accounting for a much larger portion of the global economy, which is implied by the fact that China is an import importer of commodities and electronic components, and a major source of tourists for many countries. As China's ties with the global economy become closer, the impact of China's economic slowdown on the global economy will also become greater.

Due to severe disruptions in domestic demand and supply, trade and finance, economic activity in advanced economies is expected to shrink by $7 \%$ in 2020 [8]. Emerging markets and developing economies (EMDE) are expected to shrink by $2.5 \%$ this year, the first overall contraction in at least 60 years. Per capita income is expected to fall by $3.6 \%$ and this year will plunge hundreds of millions of people into extreme poverty.

The most affected countries are those worst affected by the epidemic and that rely heavily on global trade, tourism, commodity exports and external financing. Although the degree of impact varies from region to region, all emerging markets and developing economies are vulnerable to external shocks. In addition, the disruption of schooling and basic medical services may have a lasting impact on the development of human capital. Assumed that in the middle of this year, emerging and developing economies will be eliminated later in the epidemic, the domestic epidemic prevention measures can be cancelled, and the unfavorable global spillover effects will be alleviated in the second half of the year, and the financial market will not be chaotic. Global growth is expected to rebound to $4.2 \%$ in 2021, developed economies will grow by $3.9 \%$, emerging markets and developing economies will rebound by $4.6 \%$. However, the outlook is highly uncertain and downside risks dominate. These risks include the possible duration of the epidemic, financial turmoil, and withdrawal from global trade and supply chains. The pessimistic scenario predicts that the global economy may contact by $8 \%$ this year, and then slowly recover to slightly more than $1 \%$ in 2021. Emerging markets and developing economies contact by almost $5 \%$ this year.

The United States' economy is expected to shrink by $6.1 \%$ this year, reflecting the impact of economic disruption caused by epidemic prevention and control measures. As the widespread of the epidemic has had a serious impact on economic activities, the euro zone is expected to shrink by $9.1 \%$ in 2020 . The economic recession caused by the Covid-19 is unique in many aspects. It may become the deepest recession in developed economies since World War II. It is also the first output contraction in emerging markets and developing economies in at least 60 years.

TABLE I. Covid-19 ImPacts From Different Perspectives

\begin{tabular}{|c|l|}
\hline $\begin{array}{c}\text { Regional } \\
\text { Macroeconomic } \\
\text { Impact }\end{array}$ & $\begin{array}{l}\text { Each region faces its own } \\
\text { vulnerability to the epidemic and its } \\
\text { economic downturn. }\end{array}$ \\
\hline $\begin{array}{c}\text { Impact on Global } \\
\text { Value Chains }\end{array}$ & $\begin{array}{l}\text { The disruption of global value chains } \\
\text { may amplify the impact of the } \\
\text { epidemic on trade, production and } \\
\text { financial markets. }\end{array}$ \\
\hline $\begin{array}{c}\text { Permanent scars } \\
\text { of the epidemic }\end{array}$ & $\begin{array}{l}\text { A deep recession has the potential to } \\
\text { cause long-term damage to } \\
\text { investment, erode human capital } \\
\text { through unemployment, and trigger a } \\
\text { withdrawal from global trade and } \\
\text { supply connections. }\end{array}$ \\
\hline $\begin{array}{c}\text { Economic Impact } \\
\text { of Covid-19 }\end{array}$ & $\begin{array}{l}\text { Low oil prices caused by } \\
\text { unprecedented decline in demand are } \\
\text { unlikely to mitigate the impact of the } \\
\text { epidemic but may provide some } \\
\text { support during recovery phase. }\end{array}$ \\
\hline
\end{tabular}

The Covid-19 pandemic shows that there is an urgent need for health and economic policy measures, including global cooperation to alleviate the impact of the epidemic, protest vulnerable populations, and strengthen the country's ability to prevent and respond to similar incidents in the future[9]. For particularly vulnerable emerging markets and developing economies, it is essential to strengthen public health systems and implement reforms after the crisis to promote strong and sustainable increase. 
If the impact of the epidemic continues, emerging markets and developing economics with available fiscal space and affordable financing conditions can consider increasing stimulus measures[10]. Measures to help credibly restore medium-term fiscal sustainability, including measures to strengthen the fiscal framework, which can promote domestic revenue mobilization, increase expenditure efficiency, and increase fiscal and debt transparency. The transparency of all government fiscal commitments, debt instruments, and investment is a key step in creating an attractive investment environment, and substantial progress is likely to be made this year.

\section{Research background}

According to WHO data, as of Aug 17, the Covid-19 epidemic has spread to more than 150 countries or regions, with a total of $21,294,845$ confirmed cases worldwide, and 1, 821, 055 confirmed newly diagnosed cases outside China. The Covid-19 epidemic has caused a significant impact on the world economy. On the one hand, the spread of the epidemic has accelerated on a global scale, uncertainty has risen sharply, and investor confidence has been frustrated, causing financial and capital market turmoil; on the other hand, countries have strictly restricted people's movement and transportation to control the spread of the epidemic and pressed on the economy. The economic shutdown puts pressure on economic operations from both the consumer side and the production side. The number of people diagnosed with the epidemic in various countries is positively correlated with their economic development level: countries with high GDP per capita have a higher number of diagnoses per million people.

There are three possible reasons: Firstly, in developed economies, the mobility of people is usually higher, and the degree of internationalization is also higher, which may easily cause infection and spread of the epidemic. Secondly, the aging rate of some economically developed countries is relatively high. The current clinical data shows that the elderly is more likely to be infected with Covid-19, which has also caused the increase in the number of confirmed cases in these countries. Thirdly, the healthcare system in developing countries is usually relatively backward, and the ability to conduct large-scale virus testing is insufficient, resulting in the situation that the number of confirmed cases is low. Thirdly, the current number of confirmed cases all over the world may still be underestimated. Therefore, while the world is paying attention to the prevention and control of the Covid-19 epidemic in developed countries such as the United States, Europe and Japan, it cannot ignore the spread of epidemic in developing countries. The WHO has also repeatedly emphasized that the health infrastructure of economically backward countries is weaker, and once the epidemic spreads in these countries, it may cause greater harm. The epidemic is a common challenge facing all mankind. It is increasingly necessary for countries to strengthen cooperation and support each other to fight the epidemic together.
According to the analysis of the United Nations Conference on Trade and Development, foreign direct investment (FDI), which is particularly import to developing countries, may be reduced by $40 \%$ this year, and it will not return to its previous growth rate. Last year, foreign direct investment was 1.54 trillion US dollars. This is an 3\% increase following the decline in investment in 2017 and 2018. However, according to the UNCTD, industrialized countries have particularly benefited from this, while investment in developing countries has declined slightly. Investment will continue to fall across the board by $5 \%$ to $10 \%$ next year, and there will be no recovery until 2022. Foreign direct investment is expected to fall below 1 trillion US dollars, which is the lowest level since 2005. The prospect of a severe recession will force many international companies to reconsider their investment plans, especially investments abroad. The global economy is facing severe turbulence. Even after the 2007/2008 financial crisis, cross-border investment in physical assets no longer increased significantly. World trade remains sluggish, and the global value chain is even going backwards. The debate on sustainable development has promote the trend of expanding regional production. At the same time, trade protectionism is also increasing in many parts of the world.

\section{Literature Review}

As China's largest black swan incident in early 2020, the Covid-19 epidemic, together with the US trade war, technology war, and financial war, will undoubtedly worsen the Chinese economy, which is already under great downward pressure. The state-owned economy is large in size, strong in capital, and has a lot of room for change. Correspondingly, it is less affected by the epidemic. However, private enterprises are small in size and are greatly affected by short-term market fluctuations. This shows that small and medium-sized private enterprises are the most severely affected by the epidemic.

If everyone is pessimistic about the epidemic, it will have a great impact on domestic service industry consumption. The United States is an extremely developed financial market, and the financial industry's daring to use leverage tools is the source of confidence in market growth. In the United States, the service industry accounts for the highest proportion of GDP, and the service industry has greatest impact from the epidemic. If everyone expects that the market will be affected by the outbreak and domestic consumption in the United States will be impacted, and thus lose confidence in market growth, then the United States stock market will inevitably fall for a long time. Perhaps the liquidity released by monetary policy can form a period of upward trend, but if the fundamental problem of insufficient supply due to the spread of the epidemic is not resolved, the rise can only be short-lived. Moreover, there is not much room for the United States to cut interest rates.

As the previous interest rate cuts have given the economy a booster, interest rates in the United States are now very low, and a few more times will enter the era of negative interest rates. If it truly enters the era of negative 
interest rates, it will have a great impact on the United States economy. Those pension and insurance companies that enter the market rely on long-term holding of fixedincome assets such as bonds to obtain interest as their main source of income. How to survive will be a big problem. The former British Minster of Labor, Ros Altmann, estimated that for every one percentage point drop in long-term interest rates, pension assets will shrink by $10 \%$. Therefore, many pension funds have increased the turnover ratio of incumbents, which in turn will affect consumer spending. Since negative interest rates will have an impact on social welfare, it will also aggravate social unrest.

Compared with the United States, China have strong industrial fundaments, it can resist the risk of insufficient supply caused by the Covid-19 epidemic. As long as the manufacturing industry can survive the crises of labor shortage caused by the epidemic, and resume production before the demand crisis caused by the supply crisis, it can turn the crisis into invisible term, and it can also size the opportunities originally belonging to the Unites States consumer market.

\section{Methodology}

The United States Department of Treasury has the right to provide 500 billion US dollars in loans, loan guarantees, and investments to enterprises, state and local governments. It is divided into two parts: the first is the corporate part: 25 billion dollars in passenger airlines, 4 billion dollars in cargo aviation, and 17 billion dollars in enterprises that are vital to national security. The second is 454 billion dollars in supporting the Federal Reserve's financial system state and local governments provide financial support. The Ministry of Finance, in conjunction with the Central Bank and other relevant departments, implemented special refinancing and fiscal interest discounts to reduce corporate financing costs to less than $1.6 \%$. Among them, the central bank set up a special reloan of 300 billion yuan to provide preferential loan support to key enterprises in epidemic prevention and control and daily necessities through 9 major national banks and 10 key provincial and municipal corporate banks.

In the United States, small business loans of 377 billion dollars will be converted into subsidies if the firms have no layoffs. People's Bank of China has increased the re-loan and rediscount quota of 500 billion yuan to support the resumption of work and production of small, medium and micro enterprises. As of late March, the accumulated loans with preferential interest rates have exceeded 130 billion yuan, and the loan interest rate is significantly lower than the State Council of the People's Republic of China's $4.55 \%$ requirements.

250 billion dollars have been given out to individuals and families in cash. Individuals who meet the conditions receive 1200 dollars, couples receive 2400 dollars, and minors under the age of 17 receive 500 dollars each. Individuals with an annual income of more than 75,000, those with the highest household income of more than 112 , 500 dollars, or couples with a total of more than 150,000 dollars are not eligible for this treatment. However, in China, only Hubei province has a small amount of cash issuance measures. And Nanjing, Qingdao and other places have measures to issue consumer vouchers.

In the United States, unemployment insurance is 250 billion dollars. Each unemployed individual received additional unemployment insurance of 600 dollars per week for 4 months. However, in China, the additional unemployment insurance subsidies are not provided to the unemployment individuals. However, for small, medium and micro enterprises that do not lay off or have fewer layoffs, the return standard will be increased from $50 \%$ of the unemployment insurance premium paid by the original enterprise and its employees in the previous year to the highest $100 \%$. For Hubei, it can be relaxed to all enterprises. As of now, 1.46 million enterprises have received unemployment insurance rebates this year, amounting to 22.22 billion yuan, benefiting million employees in total, and the number of beneficiary enterprises has exceeded that of last year.

In the United States, tax deferral is 300 billion dollars, including but not limited to: (1) Retailers and grocery stores, including hotels, restaurants, and supermarkets, can receive a tax subsidy of 15 billion dollars. There is great flexibility in loss tax deduction. Debt interest relief during the epidemic. (2) Payroll tax holidays. Suspend employers' payment of payroll taxes for two years. (3) Taxpayers can increase charitable donations of up to 300 dollars when using standard deductions. In China, in terms of taxation, the Ministry of Finance has issued several preferential policies for individuals, enterprises and institutions. The core contents are as follows: (1) For individuals, medical personnel and epidemic prevention workers who participate in epidemic prevention and control work shall obtain them in accordance with government standards. Temporary work subsidies and bonuses are exempted from personal income tax, drugs, medical supplies, protective equipment and other physical items (not including cash) issued to individuals for the prevention of Covid-19 are not included in wages and salary income and are exempt from personal income tax. (2) On the corporate side, for companies that produce key materials for epidemic prevention and control, newly purchased related equipment to expand production capacity is allowed to be included in the current cost and deducted before corporate income tax; for companies that are more affected by the epidemic. The longest carryforward period for losses incurred in 2020 has been extended from 5 years to 8 years. (3) In terms of government agencies and institutions, from January 1 to Mar 31, 2020, the imported materials directly used for epidemic prevention and control organized by the health authorities will be exempted from tariffs.

The United States allows borrowers to defer payment of mortgages, car loans, student loans and credit card bills. Public housing tenants suspended rent payment and suspended negative reports on consumer credit ratings. It is not allowed to auction the houses of those who fail to pay their mortgages on schedule, and not to drive out of their homes those who fail to pay their mortgages on schedule. China extended the credit card repayment period, exempted liquidated damages, and provided credit 
protection for certain people involved in the epidemic. The targets are generally medical personnel participating in epidemic prevention and control, who are affected by the epidemic and have inconvenience in repayment, and temporary loss of income source affects repayment the crowd is waiting.

\section{Results}

With the spread of Covid-19 worldwide, the global financial market has experienced sharp fluctuations, and the US stocks have broken four times in less than two weeks (Mar 9 - 18) [15-16]. In addition to the panic caused by the epidemic, the recent slowdown in world economic growth is also one of the important factors in the adjustment of capital markets. The valuation of Ashares is at a relatively low level in history. Compared with other major capital markets, the reduction in this epidemic is relatively small.

TABLE II. DATA DESCRIPTION ([11-14])

\begin{tabular}{|c|c|c|c|c|c|c|}
\hline Parameter & Mean & Min & Max & Var. & Std. Dev. & Amount \\
\hline X1 & 583.5630769 & 474.33 & 677.00 & 3324.853106 & 55.39941494 & 365 \\
\hline X2 & 10.32307692 & 7.9000 & 11.500 & 0.861923077 & 0.891976066 & 365 \\
\hline X3 & 1.223076923 & -1.8000 & 1.6000 & 0.831923077 & 0.876315579 & 365 \\
\hline X4 & 0.142307692 & 0.0000 & 1.0000 & 0.088269231 & 0.285445774 & 365 \\
\hline X5 & 5316.153846 & 0.0000 & 60,000 & 276134225.6 & 15965.37289 & 365 \\
\hline X6 & 48.69230769 & 35.700 & 50.500 & 15.40243590 & 3.770627685 & 365 \\
\hline X7 & 2121.538462 & 1850.0 & 2390.0 & 25897.43590 & 154.6134711 & 365 \\
\hline X8 & 694.6815385 & 126.80 & 1367.0 & 170356.0294 & 396.5497692 & 365 \\
\hline X9 & 5.238461538 & 3.8000 & 8.6000 & 1.650897436 & 1.234465603 & 365 \\
\hline X10 & 2943.846154 & 2650.0 & 3300.0 & 33275.64103 & 175.2597396 & 365 \\
\hline
\end{tabular}

The growth of global trade has slowed significantly in the past few years. The global trade volume in 2019 decreased by $0.5 \%$ compared with 2018 , the first decline since the global financial crises in 2008. It is expected that the Covid-19 epidemic will further reduce the growth rate of global trade. The challenges faced by countries with high trade dependence such as Germany, South Korea and Mexico will also become more severe.

TABLE III. ThE RATIO OF THE OUTPUT CHANGES TO THE CHANGES OF EACH VARIABLE ([11], [17-18])

\begin{tabular}{|c|c|c|c|}
\hline Variable & Description & $\begin{array}{c}\text { The Ratio of the Changes in the } \\
\text { United States }\end{array}$ & $\begin{array}{c}\text { The Ratio of the Changes in } \\
\text { China }\end{array}$ \\
\hline GDP & GDP Growth & 0.3168 & 0.34848 \\
\hline Epidemic & Epidemic status & -0.5544 & -0.60984 \\
\hline $\begin{array}{c}\text { Population } \\
\text { infected }\end{array}$ & Infected people & -0.5346 & -0.58806 \\
\hline PMI & Manufacturing PMI & 0.4356 & 0.47916 \\
\hline Exports & Export Income & 0.8118 & 0.89298 \\
\hline FDI & $\begin{array}{c}\text { Foreign Direct } \\
\text { Investment }\end{array}$ & -0.9504 & -1.04544 \\
\hline Industry & Industrial Productivity & 0.3762 & 0.41382 \\
\hline Stocks & Stocks Value & -0.3564 & -0.39204 \\
\hline
\end{tabular}

Global intermediate products account for more than half of all goods trade, and the global supply chain has been closely integrated. China, United States and Germany have respectively become the industrial chain hubs in East Asia, North America and Western Europe[19]. The epidemic will have an impact on the industrial chain, especially on industries with a high degree of global value chain integration, such as automobiles, electronics, and mechanical equipment. The impact will be more obvious.

The epidemic has reduced corporate revenue and affected confidence, which is not conducive to the development of multinational investment. United Nations Conference on Trade and Development (UNCTAD) predicts that the epidemic will reduce global foreign direct investment by $5 \%$ to $15 \%$ in 2020[20]. Unlike international trade and capital flows, transnational investment pays more attention to the market environment and long-term development prospects of investment destinations. China is further improving its business environment and opening to the outside world. China is still one of the important investment destinations for foreign business.

\section{Conclusions}

Firstly, if there is production, consumption can be satisfied. If there is consumption, there will be cash flow. If there is cash flow, there will be no economic crisis. Secondly, the resumption of work and production will drive the operation of the industrial chain. Only after the operation of the industrial chain can it be more effectively 
circumvented by the United States to circumvent policy of reverting manufacturing to the United States. Thirdly, if people would like to fundamentally solve the problem of insufficient supply and eliminate the slowdown in economic activities caused by the supply crisis. Finally, whoever resumes production first can seize every part of the consumer market, and the market will be reshuffled.

Also, the United States believes that the economic crisis is caused by insufficient demand, so the Fed is prepared to use a monetary policy of interest rate cuts to release liquidity to stimulate consumption. If it is to deal with ordinary economic crises caused by insufficient demand, this method may be useful. But for economic crises caused by insufficient demand, it does not seem to be effective. Because even if consumers have money in their hands, they cannot have money without spending because of a lack of goods, resulting in reduced economic activity, and ultimately due to insufficient supply and demand, triggering an economic crisis. What China has done is to use the resumption of work and production to resist the shortage of supply, and to use proactive fiscal policies to reduce the expenditures of enterprises during the epidemic. This strategy can eliminate the root cause of the economic impact of the epidemic and is also more conducive to the later period of market development.

The over-inflated faction believes that China's comprehensive national strength has surpassed the United States and that China has the strength to challenge the United States in an all-round way. Excessive pessimists only deny China's system and culture, believing that reforms have entered a deep-water zone and are difficult to advance, and the gap between China and the United States will only increase due to internal and external troubles. The rational objective group advocates a comprehensive, objective, and rational analysis of the competitiveness of China and the United States, and believe that through further reform and opening up, China is likely to achieve high-quality development, continue to catch up with the United States, continuously improve people's livelihood, and become a developed country.

\section{References}

1. Norouzi, N., de Rubens, G.Z., Choubanpishehzafar, S. and Enevoldsen, P., 2020. When pandemics impact economies and climate change: Exploring the impacts of COVID-19 on oil and electricity demand in China. Energy Research \& Social Science, 68, p.101654.

2. Van Bavel, J.J., Baicker, K., Boggio, P.S., Capraro, V., Cichocka, A., Cikara, M., Crockett, M.J., Crum, A.J., Douglas, K.M., Druckman, J.N. and Drury, J., 2020. Using social and behavioural science to support COVID-19 pandemic response. Nature Human Behaviour, pp.1-12.

3. Baker, S.R., Bloom, N., Davis, S.J., Kost, K., Sammon, M. and Viratyosin, T., 2020. The unprecedented stock market reaction to COVID-19. The Review of Asset Pricing Studies.
4. Nicola, M., Alsafi, Z., Sohrabi, C., Kerwan, A., AlJabir, A., Iosifidis, C., Agha, M. and Agha, R., 2020. The socio-economic implications of the coronavirus and COVID-19 pandemic: a review. International Journal of Surgery.

5. Kantamneni, N., 2020. The impact of the COVID-19 pandemic on marginalized populations in the United States: A research agenda.

6. Harper, C.A., Satchell, L.P., Fido, D. and Latzman, R.D., 2020. Functional fear predicts public health compliance in the COVID-19 pandemic. International journal of mental health and addiction.

7. Gostin, L.O. and Wiley, L.F., 2020. Governmental public health powers during the COVID-19 pandemic: stay-at-home orders, business closures, and travel restrictions. Jama, 323(21), pp.2137-2138.

8. Barrios, John M., and Yael Hochberg. Risk perception through the lens of politics in the time of the covid-19 pandemic. No. w27008. National Bureau of Economic Research, 2020.

9. Sheridan, A., Andersen, A.L., Hansen, E.T. and Johannesen, N., 2020. Social distancing laws cause only small losses of economic activity during the COVID-19 pandemic in Scandinavia. Proceedings of the National Academy of Sciences, 117(34), pp.20468-20473.

10. Sun, S., Lin, D. and Operario, D., 2020. Need for a population health approach to understand and address psychosocial consequences of COVID-19. Psychological Trauma: Theory, Research, Practice, and Policy, 12(S1), p.S25.

11. Allen, J., Burns, N., Garrett, L., Haass, R.N., Ikenberry, G.J., Mahbubani, K., Menon, S., Niblett, R., Nye Jr, J.S., O’Neil, S.K. and Schake, K., 2020. How the world will look after the coronavirus pandemic. Foreign Policy, 20, p.2020.

12. Wenham, C., Smith, J. and Morgan, R., 2020. COVID-19: the gendered impacts of the outbreak. The Lancet, 395(10227), pp.846-848.

13. Rao, H.R., Vemprala, N., Akello, P. and Valecha, R., 2020. Retweets of officials' alarming vs reassuring messages during the COVID-19 pandemic: Implications for crisis management. International Journal of Information Management, p.102187.

14. Dushime, C.E. and Hashemipour, S., 2020. The psychological effect of the COVID-19 pandemic in Turkey and the world at the context of political psychology. Avrasya Sosyal ve Ekonomi Araştırmaları Dergisi, 7(6), pp.75-86.

15. Silva, P.C., Batista, P.V., Lima, H.S., Alves, M.A., Guimarães, F.G. and Silva, R.C., 2020. COVIDABS: An agent-based model of COVID-19 epidemic to simulate health and economic effects of social distancing interventions. Chaos, Solitons \& Fractals, 139, p.110088.

16. Croucher, S.M., Nguyen, T. and Rahmani, D., 2020. Prejudice Toward Asian Americans in the Covid-19 
Pandemic: The Effects of Social Media Use in the United States. Frontiers in Communication, 5, p.39.

17. Omer, S.B., Malani, P. and Del Rio, C., 2020. The COVID-19 pandemic in the US: a clinical update. Jama, 323(18), pp.1767-1768.

18. Sibley, C.G., Greaves, L.M., Satherley, N., Wilson, M.S., Overall, N.C., Lee, C.H., Milojev, P., Bulbulia, J., Osborne, D., Milfont, T.L. and Houkamau, C.A., 2020. Effects of the COVID-19 pandemic and nationwide lockdown on trust, attitudes toward government, and well-being. American Psychologist. Hassan, T.A., Hollander, S., van Lent, L. and Tahoun, A., 2020. Firm-level exposure to epidemic diseases: Covid-19, SARS, and H1N1 (No. w26971). National Bureau of Economic Research.

19. Hassan, T.A., Hollander, S., van Lent, L. and Tahoun, A., 2020. Firm-level exposure to epidemic diseases: Covid-19, SARS, and H1N1 (No. w26971). National Bureau of Economic Research.

20. Van Damme, W., Dahake, R., Delamou, A., Ingelbeen, B., Wouters, E., Vanham, G., van de Pas, R., Dossou, J.P., Ir, P., Abimbola, S. and Van der Borght, S., 2020. The COVID-19 pandemic: diverse contexts; different epidemics-how and why? BMJ Global Health, 5(7), p.e003098. 